\title{
Cranial osteology of the genus Sclerurus (Passeriformes: Furnariidae)
}

\author{
Anderson Guzzi ${ }^{*}$, Mário Sérgio Duarte Branco $^{1}$ \& Reginaldo José Donatelli ${ }^{2}$ \\ 1. Departamento de Ciências do Mar, Universidade Federal do Piauí, 2819, Parnaíba, Piauí, 64202-020, Brasil; \\ guzzi@ufpi.edu.br, mariosdbranco@hotmail.com \\ 2. Departamento de Ciências Biológicas, Universidade Estadual Paulista Júlio de Mesquita Filho, Bauru, São Paulo, \\ 17001-970, C.P. 473, Brasil; rjdonat@yahoo.com.br \\ * Correspondence
}

Received 02-IX-2015. Corrected 10-III-2016. Accepted 04-IV-2016.

\begin{abstract}
The Furnariidae encompasses 293 species and has been recognized as an example of continental adaptive radiation. They inhabit biomes from deserts to humid forests at all strata and show morphological heterogeneity unparalleled among birds at any taxonomic level. Sclerurus is a uniform genus of cryptic, mainly dark brown furnariids, with short black tails which are found solitary on or near the ground inside humid forest. The aim of the present study was to describe and to compare the cranial osteology of all six Sclerurus species $(S$. scansor, S. mexicanus, S. guatemalensis, S. caudacutus, S. rufigularis, and S. albigularis) to identify osteological characters that are (1) unique to each species, (2) shared among species, and (3) that are exclusive to the genus when compared to other members of Furnariidae. For this, bone structures and measurements were done following standard methodologies. The results showed that Sclerurus differs from other Furnariidae in the following characteristics: a narrowed caudal portion of the nostril with a more rounded shape allowing upper's jaw greater mobility, used when foraging on soft substrates; the development of the post-orbital process may be related to digging behavior, as the presence of a short parsphenoid rostrum projection, a reduced cerebellar prominence, and the tapered caudal portion of the nostrils. Among the species, the interorbital width is larger in $S$. caudacutus and $S$. rufigularis, than in the remaining species. The development of the post-orbital process may be related to the behavior of digging nests in earthen banks; the narrowing of the caudal portion of the nostril allows for the greater mobility of the superior maxilla, which is used by Sclerurus when foraging in soft substrates on forest grounds. Rev. Biol. Trop. 64 (3): 1155-1170. Epub 2016 September 01.
\end{abstract}

Key words: Ovenbirds, Scleruridae, anatomy, systematic.

The avian family Furnariidae encompasses 293 species and has been recognized as an example of continental adaptive radiation (Fjeldså, Irestedt, \& Ericson, 2005; Moyle et al., 2009; Derryberry et al., 2011). It is endemic to the Neotropical region and comprises $51 \%$ of the Suboscines passerine species and $11 \%$ of the Passeriformes species (Claramunt, 2010). They inhabit biomes from deserts to humid forests at all strata (Chesser, Barker, \& Brumfield, 2007), and show morphological heterogeneity unparalleled among birds at any taxonomic level (Leisler, 1977; Vaurie, 1980; Remsen, 2003; Fjeldså, et al., 2005; Irestedt, Fjeldså, $\&$ Ericson, 2006). The group includes many examples of species that exhibit superficial morphological similarities with other phylogenetically distant taxa, such as members of the families Turdidae, Cinclidae, Alaudidae, and Mimidae, and many Synallaxinae genera resemble Old World Sylviidae members or Certhiidae (Irestedt, et al., 2006). Furnariidae nests exhibit an extraordinary diversity in placement and structure, and the variation among the family's nest types has been suggested to be the largest within Aves (Zyskowski \& Prum, 1999; Irestedt, et al., 2006).

Furnariidae have traditionally been divided into three major groups: Furnariini, the ground dwellers; Synallaxini, with long and distinct 
tails; and Philydorini, the forest dwellers (Hellmayr, 1925; Vaurie, 1971, 1980; Sibley \& Ahlquist, 1990). Feduccia (1973) observed cranial similarities between certain Dendrocolaptidae and Philydorinae, suggesting that Dendrocolaptidae evolved from Philydorinae members. Several recent, DNA-based studies have supported the hypothesis of closer phylogenetic relationship between Dendrocolaptidae and Furnariidae that was proposed by Feduccia (1973), but have rejected the hypothesis of an affinity with the Philydorinae, a group considered by Irestedt et al. (2006) to be artificial. Instead, it has been suggested that Sclerurus and Geositta form a basal monophyletic group for both Dendrocolaptidae and Furnariidae and that both groups are mutually monophyletic (Irestedt, Johansson, Parsons, \& Ericson, 2001; Irestedt, Fjeldså, Johansson, \& Ericson, 2002; Chesser, 2004; Fjeldså, et al., 2005; Olson, Irestedt, Ericson, \& Fjeldså, 2005; Moyle, et al., 2009). Based on these molecular-based phylogenies studies, Moyle et al. (2009) suggested the subfamily Sclerurinae, firstly proposed by Sclater (1862), defended by Swainson (1827), and later raised by Irestedt et al. (2002; 2006), Irestedt, Fjeldsa and Ericson (2004) and Chesser (2004) to the family level (Scleruridae), composed of species belonging to the Sclerurus and Geositta genera (Irestedt, et al., 2001; Irestedt, et al., 2002; Chesser, 2004; Fjeldså, et al., 2005; Olson, et al., 2005; Irestedt, et al., 2006; Moyle, et al., 2009), while Derryberry et al. (2011) maintains Sclerurinae as the most basal subfamily of the Furnariidae.

The genus Sclerurus has traditionally been positioned close to Automulus and Lochmias, among the Phylidorini, for being considered pseudoschizorhinous, having four notches on the sternum, and having poorly developed pectoral muscles, similar to basal tracheophone birds (Irestedt, et al., 2002). Although they forage like terrestrial Furnariidae, Sclerurus have a rigid tail that supports short flights to trees and trunks when alarmed (Skutch, 1969), as well as for arboreal roosting (Van Els \& Whitney, 2011). The rigid tail is shared by Sclerurus, Dendrocolaptidae, and several taxa distributed among all Furnariidae clades, and it may represent a derived character for the family, which has been modified or lost in a number of terminal taxa and has been well developed as a rising support in Dendrocolaptidae and Pygarrhycas (Irestedt, et al., 2002). The most recent common ancestor of Furnariidae had not any adaptations for tail-assisted climbing. Thus it is believed that in all Dendrocolaptidae, Sclerurus, Magarornis, Berlepshia and Xenops, rachis stiffness and elongated outer toes were independently acquired (Claramunt, Derryberry, Remsen Junior, \& Brumfield, 2011). Sclerurus consists of six species, $S$. scansor, $S$. mexicanus, $S$. guatemalensis, $S$. caudacutus, $S$. rufigularis, and $S$. albigularis. These species are strictly forest taxa, with a high sensitivity to environmental changes, and distributed among the major Neotropical forests (Central American forests, Amazonia, Andes, and Atlantic Forest) (Skutch, 1969; Vaurie, 1980; Ridgely \& Tudor, 1994; D'Horta, Cuervo, Ribas, Brumfield, \& Miyaki, 2013). The aim of the present study was to describe and to compare the cranial osteology of the six Sclerurus species to identify osteological characters that are unique to each species, that are shared among the species, and that are exclusive to the genus when compared to other members of Furnariidae.

\section{MATERIALS AND METHODS}

The cranial anatomy was described for all species of the genus Sclerurus: S. mexicanus; S. rufigularis; S. albigularis; S. caudacutus; S. scansor; and S. guatemalensis. The osteology of $S$. mexicanus was described to serve as a reference for comparisons with the other Sclerurus species studied. A ZEISS SV6 stereomicroscope (10x ocular and objective lenses ranging from 0.8 to $5.0 \mathrm{x}$ ) was used to aid in the general identification of the structures. A $300 \mathrm{~mm}$ Mitutoyo caliper was used to measure the various bone structures, and the measurements presented are the results of an average of three measurements of the same structure in each skull. 
All specimens examined were previously prepared (dried skull and jaws) and belong to the collection of the Emílio Goeldi Paraense Museum (Museu Paraense Emílio Goeldi MPEG), Belém, Pará, Brazil, and to the collection of the National Museum of Natural History (USNM), Smithsonian Institution, Washington, DC, USA, namely: S. caudacutus [MPEG 1 771 (1972)]; USNM 614 891; and USNM 562 274), S. rufigularis [MPEG 1706 (1973)]; USNM 492 236; USNM 620 154; USNM 492 308; USNM 492 333; USNM 621 752; USNM 621 995), S. guatemalensis (USNM 288 844; USNM 432 600), S. mexicanus [MPEG 3053 (1974)]; USNM 562 272; USNM 562 271; USNM 562 273; USNM 613 305; USNM 432 620), S. albigularis (USNM 491 827; USNM 344 231; USNM 491 826; USNM 491 828; USNM 614 121; USNM 491 825; USNM 491 827), and S. scansor (USNM 561 299).

Because the species' skulls varied considerably in size and some bone structures varied significantly among species, we sought to comparatively determine the relative size of each structure by measuring the distance of the origin of the structure to the corresponding bone structure, and this orientation was followed for all species after homologies were determined. Following this principle, we sought to standardize terms, such as "deep" and "developed", used in the anatomical description of osteological structures that are difficult to measure, such as fossae or crests, in a comparative manner.

The nomenclature used in the present osteological descriptions followed the Nomina Anatomica Avium (Baumel, King, Lucas, Breazile, \& Evans, 1993).

\section{RESULTS}

Ossa cranii: The frontal region (Os frontale - F) (Fig. 1 and Fig. 2) of S. mexicanus occupies a large section of the cranial roof, approximately half of the total length of the skull. The interorbital width is approximately $1 / 5$ of the parietal region, a ratio also found in $S$. albigularis and $S$. scansor; whereas the ratio is $1 / 4$ in $S$. guatemalensis and $1 / 3$ in the other species. The frontal region articulates rostrally with the nasal region via the zona flexoria craniofacialis (ZFC) (Fig. 1, Fig. 2, Fig. 3 and Fig. 4) and exhibits a rostral protuberance in the frontal bone (PF) (Fig. 1B and Fig. 1C) in both S. caudacutus and S. rufigularis, and a median rostral concavity in the frontal bone (median rostral concavity - CRM) (Fig. 1A and Fig. 2) is present in all species except $S$. caudacutus and $S$. rufigularis. The frontal region is continuous caudally with the wide parietal region and laterocaudally with the short post-orbital process. Lacrimal bones (ossa lacrimalis) were not observed in these species or were fused rostrolaterally with the frontal bone region during development.

The wide parietal region (Os parietale $-\mathrm{P}$ ) (Fig. 1, Fig. 2, Fig. 3 and Fig. 4) borders the squamosal region lateroventrally at the inconspicuous superior temporal crest (Crista temporalis - CrTS) (Fig. 3); laterocaudally, the parietal region comes into contact with the occipital region via the transverse nuchal crest (Crista nuchalis transversa-CrNT) (Fig. 3). The ratio found between the interorbital width and the parietal region varies from five times in S. mexicanus, S. scansor, and S. albigularis to four times in $S$. guatemalensis and three times in the remaining species.

The squamosal region (Os squamosum - S) (Fig. 3 and Fig. 4) is bounded laterodorsally by the superior temporal crest (Crista temporalis - CrTS) (Fig. 3), which occupies a small part of the lateral portion of the skull, extending caudally to the post-orbital process; ventrocaudally, the squamosal region is bounded by the reduced suprameatic process (Processus suprameaticus - PrS) (Fig. 3 and Fig. 4) and by the external auditory meatus (Meatus acusticus externus - MAE) (Fig. 3 and Fig. 4). All Sclerurus species have a depression at the extremities of the lateral edges of the skull (cranial roof lateral depression - DrL) (Fig. 1 and Fig. 2). The temporal fossa (Fossa temporalis - FT) (Fig. 3 and Fig. 4) is shallow in all its extensions and is rostrocaudally longer than wide in all species; it is shallower in $S$. mexicanus, S. guatemalensis, S. scansor, and 

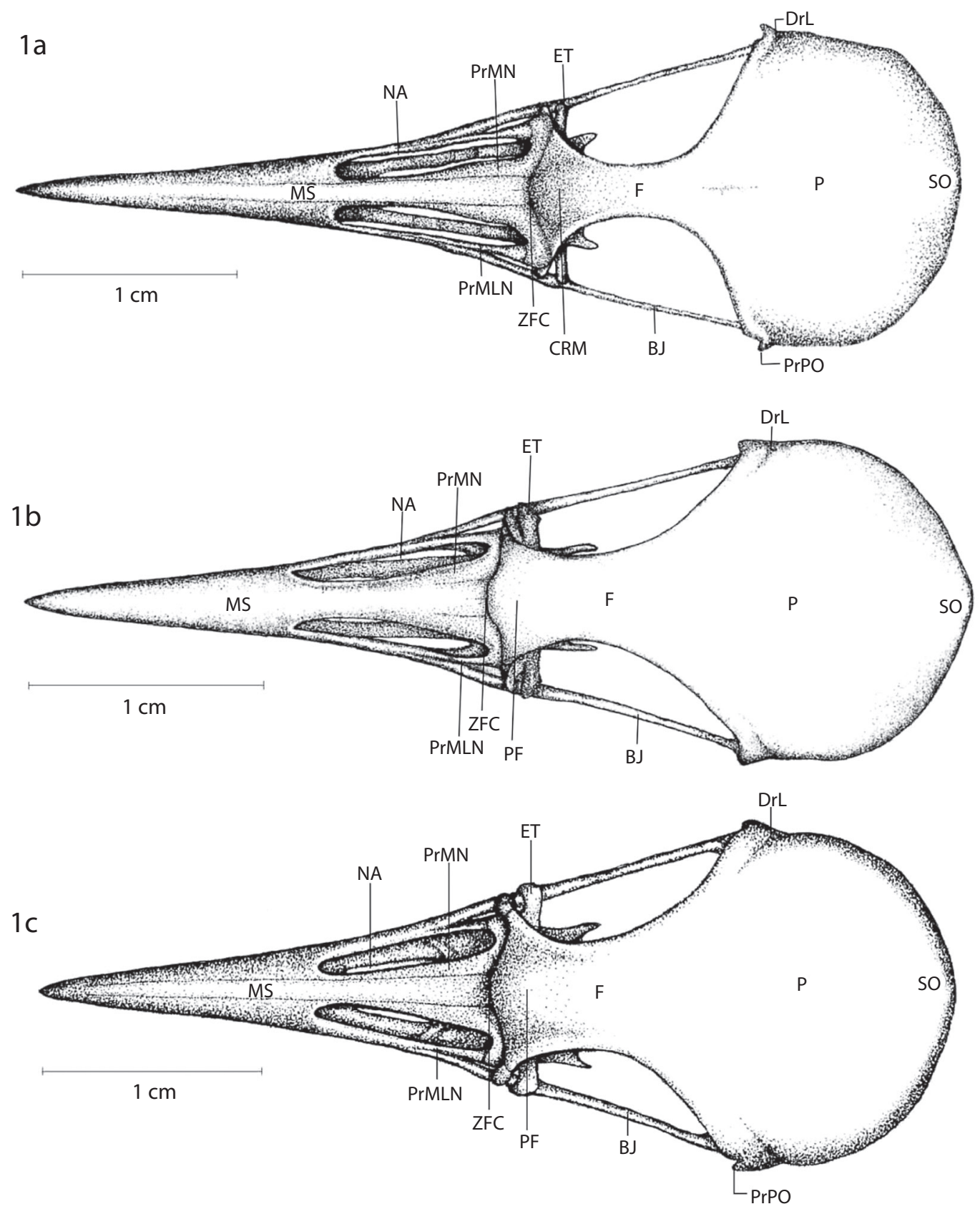

Fig. 1. Dorsal view of the skull of the Sclerurus species. a) S. mexicanus. b) S. caudacutus. c) S. rufigularis. Legend: $\mathrm{BJ}$ - jugal bar; CRM - median rostral concavity; DrL - lateral depression of the roof of the skull; ET - ectethmoid; F frontal bone region; MS -superior maxilla; NA - nostril; $\mathrm{P}$ - parietal bone region; $\mathrm{PF}$ - frontal bone rostral protuberance; PrMN - nasal bone maxillary process; PrMLN - nasal bone lateral maxillary process; PrPO -post-orbital process; $\mathrm{SO}$ supraoccipital; ZCF - zona flexoria craniofacialis. 

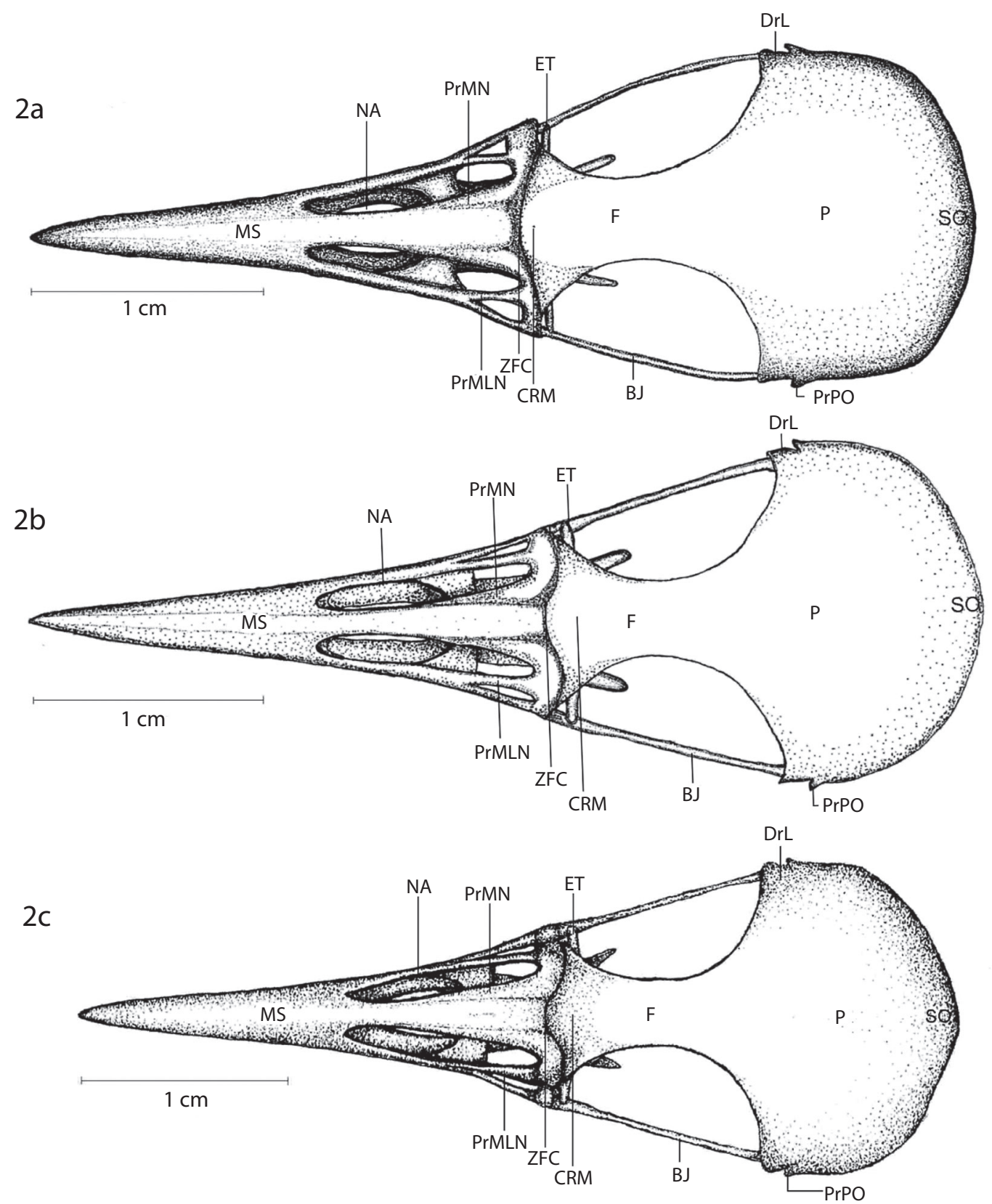

Fig. 2. Dorsal view of the skull of the Sclerurus species. a) S. guatemalensis. b) S. scansor. c) S. albigularis. Legend: BJ - jugal bar; CRM - median rostral concavity; DrL - lateral depression of the roof of the skull; ET - ectethmoid; F frontal bone region; MS -superior maxilla; NA - nostril; $\mathrm{P}$ - parietal bone region; PF - frontal bone rostral protuberance; PrMN - nasal bone maxillary process; PrMLN - nasal bone lateral maxillary process; PrPO - post-orbital process; SO supraoccipital; ZCF - zona flexoria craniofacialis. 


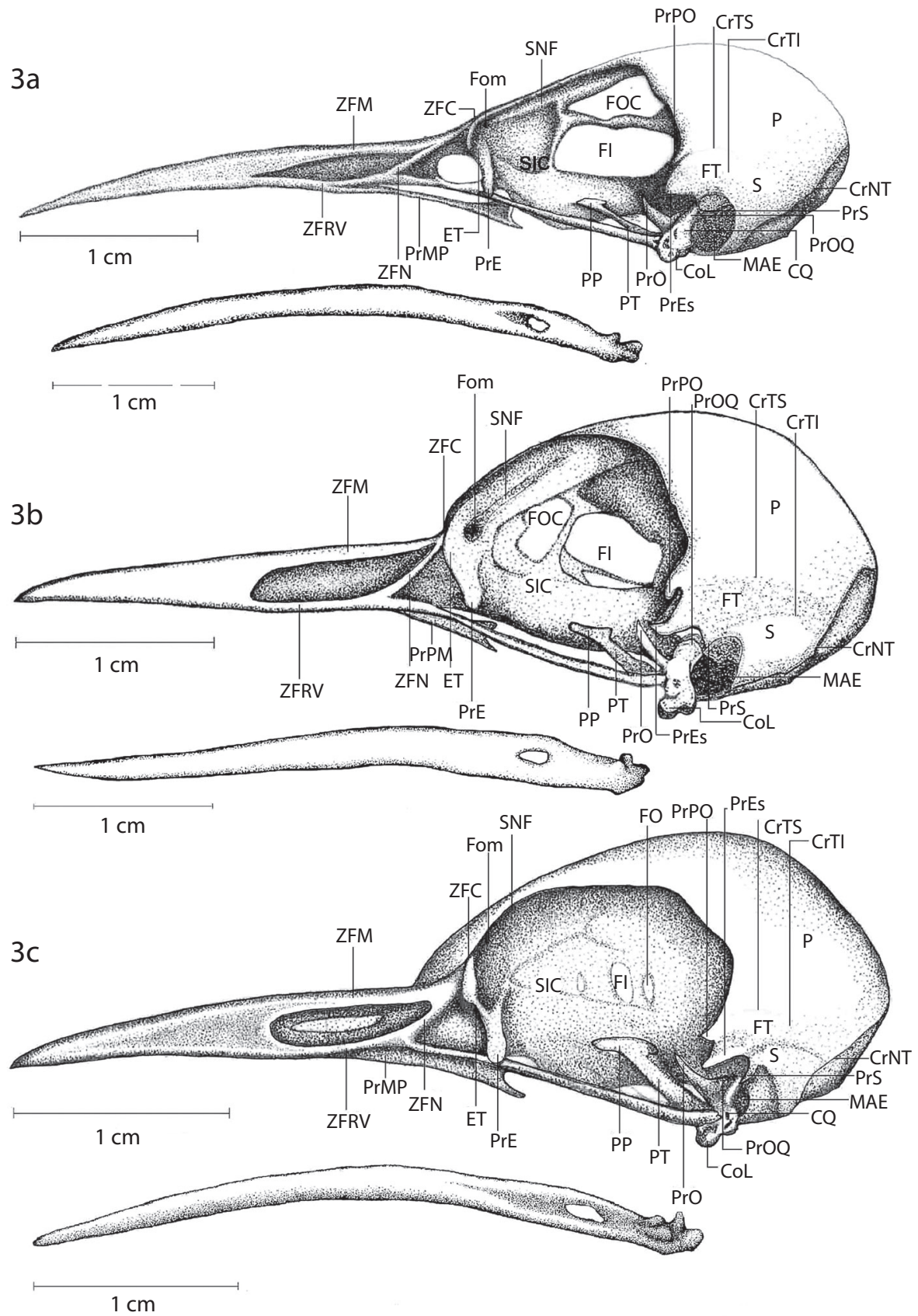

Fig. 3. Lateral view of the skull and mandible of the Sclerurus species. a) S. mexicanus. b) S. caudacutus. c) S. rufigularis. Legend: Com - quadratus medial condyle; CQ - quadratus bone; CrTI - inferior temporal crest; CrNT - transverse nuchal crest; CrTS- superior temporal crest; S - squamosal region; ET - ectethmoid; FI - interorbital fonticulus; FO - optic foramen; FOC - orbitocranial fonticulus; Fom - medial orbitonasal foramen; FT - temporal fossa; MAE - external acoustic meatus; P - parietal bone region; PP - pterygoid rostral process; PrE - ectethmoid process; PrMP - maxillopalatine process; $\mathrm{PrO}$ - orbital quadratus process; PrOQ - optic quadratus process; PrPO - post-orbital process; PrS - suprameatic process; PrEs - squamosal process; PT - pterygoid; SIC - interorbital septum; SNF - olfactory nerve sulcus; ZFC - zona flexoria craniofacialis; ZFM - zona flexoria medialis; ZFN - zona flexoria nasalis; ZFRV - zona flexoria rostroventralis. 


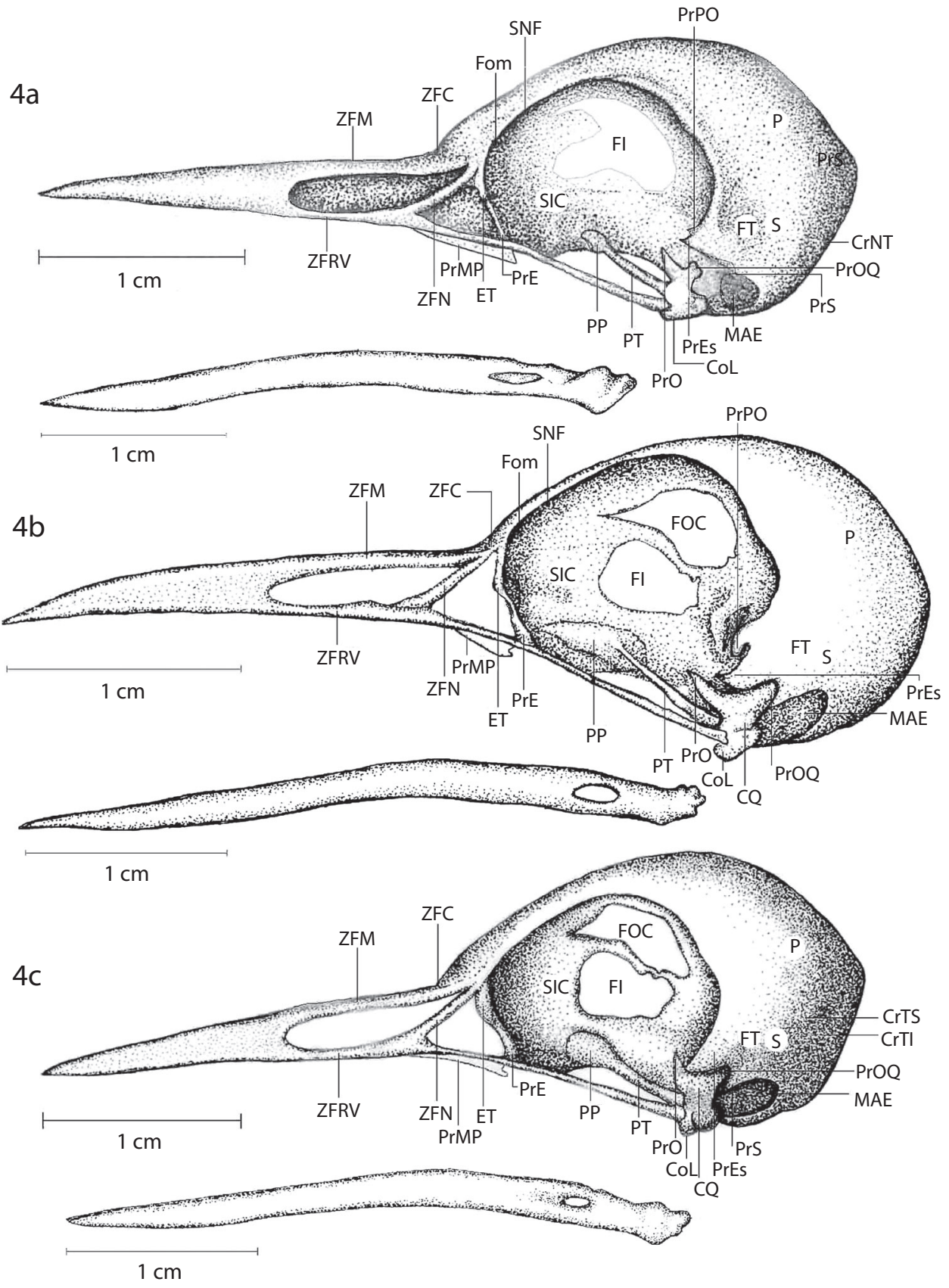

Fig. 4. Lateral view of the skull and mandible of the Sclerurus species. a) S. guatemalensis. b) S. scansor. c) S. albigularis. Legend: Com - quadratus medial condyle; CQ - quadratus bone; CrTI - inferior temporal crest; CrNT - transverse nuchal crest; CrTS- superior temporal crest; S - squamosal region; ET - ectethmoid; FI - interorbital fonticulus; FO - optic foramen; FOC - orbitocranial fonticulus; Fom - medial orbitonasal foramen; FT - temporal fossa; MAE - external acoustic meatus; P - parietal bone region; PP - pterygoid rostral process; PrE - ectethmoid process; PrMP - maxillopalatine process; $\mathrm{PrO}$ - orbital quadratus process; PrOQ - optic quadratus process; PrPO - post-orbital process; PrS - suprameatic process; PrEs - squamosal process; PT - pterygoid; SIC - interorbital septum; SNF - olfactory nerve sulcus; ZFC - zona flexoria craniofacialis; ZFM - zona flexoria medialis; ZFN - zona flexoria nasalis; ZFRV - zona flexoria rostroventralis. 
S. albigularis and is deeper in the other species (Fig. 3 and Fig. 4).

The squamosal region is projected rostrally and forms the squamosal process (PrEs) (Fig. 3 and Fig. 4). The process is long and wide at its base and has a characteristic triangle shape, occupying approximately $3 / 5$ of the distance between its origin on the skull and the jugal bar (arcus jugalis) in S. mexicanus and S. albigularis; $1 / 3$ in $S$. guatemalensis and $S$. scansor; and $1 / 2$ in the other species.

The post-orbital process (Proc. postorbitalis - PrPO) (Fig. 3 and Fig. 4) is short and little developed but wide at its base and is approximately $1 / 3$ of the distance between its origin on the skull and the jugal bar in $S$. caudacutus (Fig. 3B) and S. scansor (Fig. 4B); $1 / 4$ in S. mexicanus (Fig. 3A), S. guatemalensis (Fig. 4A), and S. albigularis (Fig. 4C); and 1/5 in S. rufigularis (Fig. 3C).

The exoccipital region is delimited by the tympanic ala (Cavum tympanicum - AT) (Fig. 5 and Fig. 6) via the short paraoccipital process (Proc. paraoccipitalis - PrP) (Fig. 5 and Fig. $6)$. The cerebellar protuberance of the supraoccipital bone protrudes slightly in all Sclerurus species, except in S. caudacutus (Fig. 5B).

In the parasphenoid bone region (Os parasphenoidale), the parasphenoid rostrum (Rostrum parasphenoidale - RP) (Fig. 5 and Fig. 6) stands out; it is of homogeneous size among the species studied, except in S. scansor, where the delimitation of the parasphenoid bone is more oval and continuous with the basioccipital region. A projection of the rostroparasphenoid bone (PrJ) (Fig. 5 and Fig. 6) is present in this region, which is short in $S$. mexicanus and S. guatemalensis and long in the other Sclerurus species.

Orbita: The ectethmoid (Os ectethmoidale - ET) (Fig. 1, Fig. 2, Fig. 3 and Fig. 4) is shaped like a flattened "Y" in $S$. mexicanus (Fig. 3A) and S. albigularis (Fig. 4C); in the other species, it is flattened. The ectethmoid has a characteristic ventrolateral extension, the ventrolateral ectethmoid process (PrE) (Fig. 3 and Fig. 4). This structure reaches the jugal bar laterally in all species, except $S$. caudacutus (Fig. 3B). The "T" tuberculum is present in the ventromedial portion of the laterosphenoid region, is reduced in S. caudacutus and $S$. rufigularis, and is well developed in the other species.

Ossa Maxillae et Palati: The superior maxilla (MS) (Fig. 1 and Fig. 2) is approximately $60 \%$ of the total length of the skull in S. mexicanus, S. albigularis, S. rufigularis, $S$. scansor, and $S$. guatemalensis, and $50 \%$ in S. caudacutus. The nostrils (NA) (Fig. 1 and Fig. 2) are oval and classified as schizorhinous in Sclerurus. The most caudal portions of the Sclerurus nostrils are tapered and are $1 / 2$ of the total length of the superior maxilla in all species. The nasal bone's lateral maxillary process (PrMLN) (Fig. 1, Fig. 2) is narrow, long, and slanted; the dorsal bars of the maxillary process of the long nasal bone taper rostrally, delimit the dorsocaudal portion of the nostril, and have a homogeneous configuration across the species studied.

The medial palatine crests (Crista medialis - CrM) (Fig. 5 and Fig. 6) are prominent and emit the long and rostrally tapered rostral processes, which are more medially situated, and delimit the choanal fossa (fossa choanalis -FC) (Fig. 5 and Fig. 6). The transpalatine process is long and pointed in all species (PrTP) (Fig. 5 and Fig. 6).

The lateral condyle of bone quadrate (Condylus lateralis - CoL) (Fig. 5 and Fig. 6) is long and more robust than the medial condyle, articulates with the jugal bar laterally from a dorsal process, is longer in S. caudacutus, S. rufigularis, S. guatemalensis, and $S$. scansor, and is shorter in the other species; the caudal condyle of bone quadrate (Condylus caudalis - $\mathrm{CoC}$ ) (Fig. 5 and Fig. 6) is an extension of the lateral condyle, which it is fused with, is rounded in S. caudacutus, S. rufigularis, S. guatemalensis, and $S$. scansor, and is less rounded in the other species. The pes pterygoidei is developed in $S$. rufigularis and S. scansor; is developed medially in $S$. albigularis, and is less developed in the other species. 

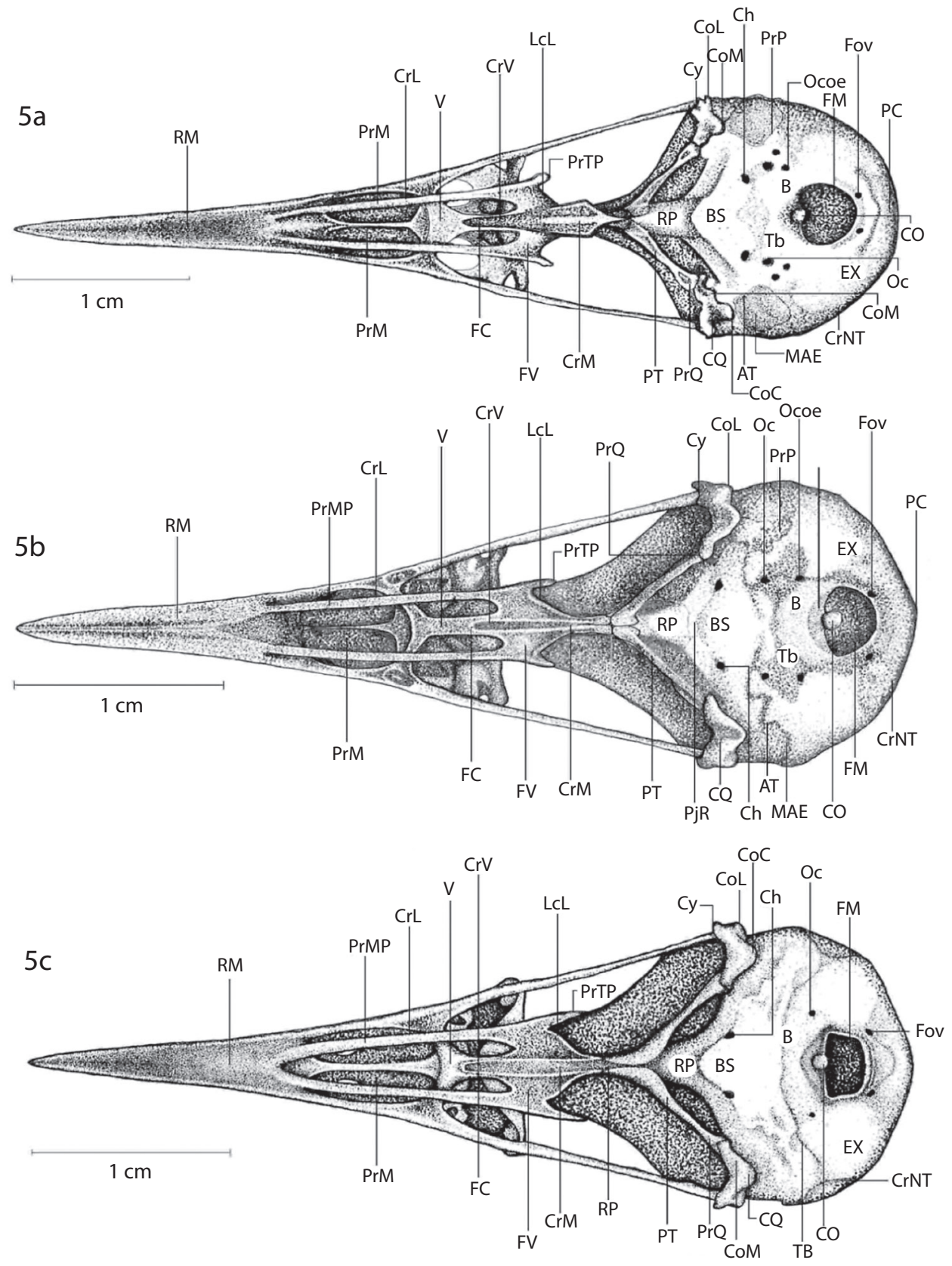

Fig. 5. Ventral view of the skull of the Sclerurus species. a) S. mexicanus. b) S. caudacutus. c) S. rufigularis. Legend: AT - tympanic ala; B - basioccipital region; BS -basisphenoid region; $\mathrm{Ch}$ - hypoglossal nerve channel; CO - occipital condyle; $\mathrm{CoC}$ - caudal quadratus condyle; $\mathrm{CoL}$ - lateral quadratus condyle; $\mathrm{CoM}$ - medial quadratus condyle; $\mathrm{CrL}$ - lateral palatine crest; $\mathrm{CrM}$ - medial palatine crest; $\mathrm{CrNT}$ - transverse nuchal crest; $\mathrm{CrV}$ - ventral palatine crest; $\mathrm{Cy}$-quadradojugal cotyla; EX - exoccipital region; FC - choanal palatine fossa; FM - magnum foramem; Fov - vagus nerve foramem; Fs subcondylar fossa; FV - ventral fossa; LcL - caudolateral lamella; MAE - external acoustic meatus; Oc - cranial carotid channel ostium; Ocoe - external ophthalmic channel opening; PC - cerebellar protuberance; PrM - maxillopalatine process; PrMP - maxillary palatine process; PrP - paraoccipital process; PrQ - quadratic process; PrTP - transpalatine process; PS - parasphenoid; PT - pterygoid; RM - maxillary rostrum; RP - parasphenoid rostrum; Tb - basilar tuberculum; V - vomer. 

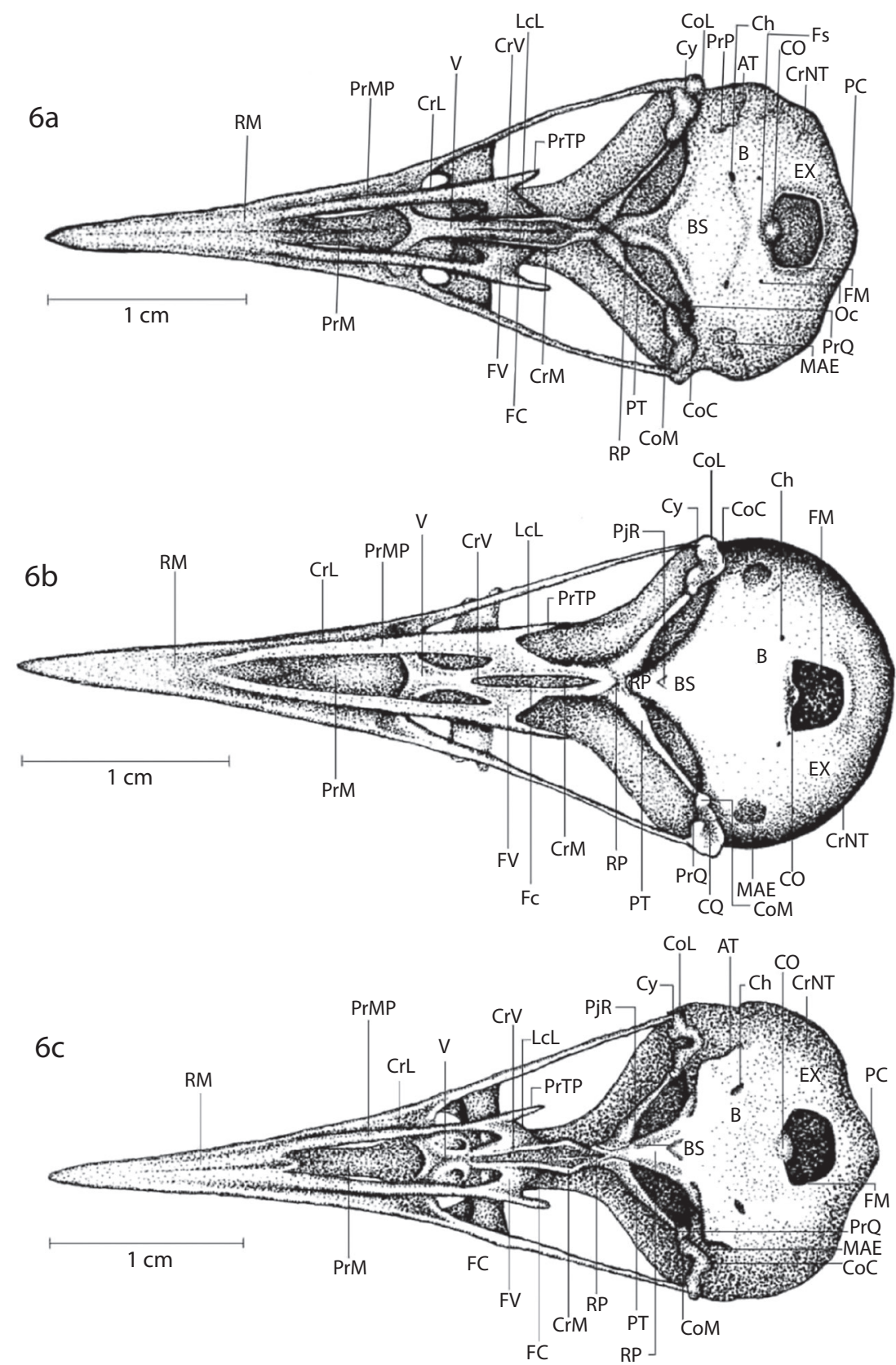

Fig. 6. Ventral view of the skull of the Sclerurus species. a) S. guatemalensis. b) S. scansor. c) S. albigularis. Legend: AT - tympanic ala; B - basioccipital region; BS -basisphenoid region; $\mathrm{Ch}$ - hypoglossal nerve channel; CO - occipital condyle; $\mathrm{CoC}$ - caudal quadratus condyle; $\mathrm{CoL}$ - lateral quadratus condyle; $\mathrm{CoM}$ - medial quadratus condyle; $\mathrm{CrL}$ - lateral palatine crest; $\mathrm{CrM}$ - medial palatine crest; $\mathrm{CrNT}$ - transverse nuchal crest; $\mathrm{CrV}$ - ventral palatine crest; $\mathrm{Cy}$-quadradojugal cotyla; EX - exoccipital region; FC - choanal palatine fossa; FM - magnum foramem; Fov - vagus nerve foramem; Fs subcondylar fossa; FV - ventral fossa; LcL - caudolateral lamella; MAE - external acoustic meatus; Oc - cranial carotid channel ostium; Ocoe - external ophthalmic channel opening; PC - cerebellar protuberance; PrM - maxillopalatine process; PrMP - maxillary palatine process; PrP - paraoccipital process; PrQ - quadratic process; PrTP - transpalatine process; PS - parasphenoid; PT - pterygoid; RM - maxillary rostrum; RP - parasphenoid rostrum; Tb - basilar tuberculum; V - vomer. 
Ossa mandibulae: The mandibular symphysis (pars symphisialis mandibulae) occupies approximately $1 / 3$ of the total length of the mandible in all species studied. The poorly developed medial process (Proc. medialis mandibulae) projects dorsomedially and is wide at the base, tapering distally in all species, except in $S$. caudacutus and $S$. rufigularis, where it is shorter.

\section{DISCUSSION}

The interorbital width had three distinct developments, with the largest being present in S. caudacutus and S. rufigularis. There was a reduction in the interorbital widths of S. mexicanus, S. albigularis, S. scansor, and $S$. guatemalensis. This reduction has been the focus of discussion for some authors, e.g. Burton (1984), Pascotto and Donatelli (2003), who related it with an increased amplitude in the visual field. The increased superposition of the visual field may provide an increase in the ability to hunt for insects or other small arthropods, which constitute the main diet of Sclerurus, as described by Vaurie (1980), Ridgely and Tudor (1994), as well as by Mestre et al. (2010). Zusi (1984) stated that the binocular vision of some birds required a reduction of the anterorbital region, which was observed in $S$. mexicanus, $S$. albigularis, S. scansor, and $S$. guatemalensis. Other authors viewed the interorbital width pattern with a systematic focus, such as Donatelli and Marceliano (2007) in their study on Megaxenops parnaguae, where they stated that a greater interorbital width as characteristic to all Furnariinae, when compared to species of other subfamilies.

The zona flexoria craniofacialis, according to Feduccia (1973), is known to be an area of narrowing in the caudal region of the nasal bones. The author stated that the zona flexoria craniofacialis in Furnariidae, except for Philydorinae, was narrow compared to that of woodcreepers, a fact that was not observed by Donatelli (1997). Donatelli and Marceliano (2007) stated that the zona flexoria craniofacialis was limited to the median region between the frontal and nasal bone regions in Synallaxinae and Philydorinae but not in Furnariinae. This condition was not observed by Feduccia (1973), who clearly separated the Philydorinae from the other subfamilies, attributing to the former a condition similar to that of Dendrocolaptidae. Any discussion about the conformation of zona flexoria craniofacialis requires an analysis of the cranial kinesis of the bird species studied. Feduccia (1973) classified the Furnariidae (except for Philydorinae) as pseudoschizorhinous, a term originally proposed by Fürbringer (1888). This author differentiated the schizorhinous condition presented by the Furnariidae (except for the holorhinous Philydorinae) as non-homologous to the condition observed in other avian orders, traditionally classified as schizorhinous. Zusi (1993) emphasized the importance of the correct usage of the terminology because all schizorhinous birds are rhynchokinetic, but many rhynchokinetic birds are not schizorhinous. According to Zusi (1993), the terms holorhinous and schizorhinous were originally proposed by Bock and Mcevey (1969). Zusi (op. cit.) emphasized the functional differences between both types but are not applicable to species wherein the nostrils end near or at the level of the frontonasal suture, as in Furnariidae. Thus, he noted that there were different types of craniofacial kinesis in Furnariidae, ranging from rhynchokinesis (proximal, double, and extensive) to prokinesis (holorhiny). Automolus is typically holorhinous, according to Feduccia (1973), as is most Philydor species, according to Zusi (1993). The species in the present study are classified as schizorhinous and, more precisely, as proximally rhynchokinetic. The positions and forms of the zona flexoria craniofacialis are homogeneous among Sclerurus species, with no variations observed. When compared to other Furnariidae, Sclerurus have a narrowed caudal portion of the nostril, in contrast with other species, where the region ends in a more rounded shape. Following the analysis by Zusi (1993), the narrowing permits the greater mobility of the superior maxilla, which is used by many species when foraging in soft substrates, as 
is the case for Sclerurus (Vaurie, 1980). Such species can close the tip of their thin bills while holding prey, as evidenced by Zusi (1993), thus preventing alternative routes of escape for the prey. Fjeldså et al. (2005) stated that Dendrocolaptidae have a typical holorhinous condition. The skulls of Sclerurus and Geositta have an intermediate condition compared to Dendrocolaptidae, especially Sclerurus, whose skull is very similar to Dendrocincla and Sittasomus skulls but with a thinner beak base.

Donatelli and Marceliano (2007) stated that the maxillary process of the nasal bone (the nasal process of the pre-maxilla described by Feduccia, 1973) was similar between Synallaxinae and Philydorinae and that this process was not observed in Furnariinae. In contrast, Zusi (1993) stated that in many Furnariidae (especially Philydor) and in Dendrocolaptidae, prokinesis may have evolved from proximal rhynchokinesis. He added that the reason is because the zona flexoria rostroventralis of the maxillary process of the nasal bone in the species is flattened, which provides more versatility in the opening and closing movements of the bill. Zusi (1993) also stated that the proximally rhynchokinetic Furnariidae, such as Margarornis rubiginosus and Furnarius leucopus, may have evolved from ancestral doubly rhynchokinetic furnariids and other species or from furnariids with extensive rhynchokinesis. The rhynchokinesis of Neognathae was considered by Zusi (1993) to be an apomorphic condition among birds, derived from the ancestral prokinetic condition with wide nasal openings. $\mathrm{He}$ pointed out that there is no record of this character state in the majority of modern birds, in fossil species, in Archaeopteryx, in Crocodylia, or in Coelurosauria. Therefore, the appearance of the holorhinous nostril condition in some Philydorinae (and also in Dendrocolaptidae) is thought to be a typical case of reversion, derived from the rhynchokinetic condition of Neognathae (Feduccia, 1973; Zusi, 1993).

The temporal fossa is longer than wide in all Sclerurus species, being shallow in $S$. caudacutus and S. rufigularis and deeper in $S$. guatemalensis, S. scansor, S. albigularis, and
S. mexicanus. Asthenes modesta, a species that Feduccia (1973) chose as being representative of the group formed by pseudoschizorhinous Furnariidae, (hereafter denominated the SFS group: Synallaxinae, Furnariinae, and Scleruninae), has a shallow temporal fossa compared to that of the intermediate species (holorhinous Philydorinae). In Dendrocolaptidae, the postorbital and squamosal processes are fused (Feduccia, 1973), which modifies the location and origin of the mandibular adductor muscles. Thus, a direct comparison cannot be made between the temporal fossa of species that clearly possess this fusion and those of species that do not possess this fusion.

The post-orbital process is long in $S$. scansor and $S$. caudacutus, intermediate in $S$. mexicanus, S. albigularis, and S. guatemalensis, and short in S. rufigularis. Donatelli and Marceliano (2007) observed a smaller development of the post-orbital process in Megaxenops.

Zusi (1984) stated that the presence of the post-orbital ligament, coupled with the actions of the os quadratum and of the muscles which move the maxillae, allows the opening of the superior and inferior maxillae together in a single movement. The intricate lever system may have redefined muscle action adding speed and synchronism. This might have increased success in foraging behavior in the species that possessed it (Mestre et al., 2010). Those authors stated that, among the species they studied in Amazonian forest fragments, $S$. rufigularis foraged by turning leaves and searching for insects by inserting its bill in the ground (Ridgely \& Tudor, 1994). Thus this species selected Coleoptera larvae and larger prey than those selected by the other species they studied. Many Furnariidae maintained the primitive scansorial habit either on the soft ground of forests (as Sclerurus), or at tree branches (Aphrastura, Berlepschia and Xenops) where the highest degree of specialization is found (Dendrocolaptinae; and Pygarrhichini Margarornis). These species remained in South America about 15 million years without competition from woodpeckers, and had enough time for specialization in this type of 
niche (Claramunt, Derryberry, Brumfield, \& Remsen Junior, 2012). Feduccia (1973) stated that the post-orbital and squamosal processes of Asthenes modesta were fused, forming a foramen for the passage of the adductor muscles. Donatelli and Marceliano (2007) asserted that "foramen" was not an appropriate term in this case (see Baumel, et al., 1993) and such fusion was not observed by them in any Furnariidae. In Sclerurus, the post-orbital and squamosal processes are distinct structures. The squamosal process is shorter in $S$. scansor and $S$. guatemalensis. Between the post-orbital and squamosal processes, there is a discrete temporal fossa, indicating the presence of a slender mandibular adductor muscle. Feduccia (1973) stated that the bone structures in Automolus were intermediate between those of Furnariidae, (considered pseudoschizorhinous) and those of Dendrocolaptidae. He also observed that the squamosal and post-orbital processes were well developed in Automolus, characteristics also observed in Dendrocolaptidae and in this study.

Feduccia (1973) emphasized that many skull characters were correlated with foraging behavior and prey type. He pointed out that many Furnariidae feed on small insects, whereas Dendrocolaptidae feed on larger insects and small vertebrates that inhabit tree trunks, such as frogs and lizards. Moreover, the differences in diet may have been related to the differences in skull structures, which were more robust in Dendrocolaptidae. The phylogenetic hypothesis of Irestedt et al. (2004) suggested that the long bills of Dendrocolaptidae evolved independently more than once. Some woodcreepers however have a closer phylogenetic proximity to Furnariinae with short bills. Moreover, the rachis stiffness and elongated outer toes that were independently acquired in Sclerurus and Dendrocolaptidae, and the most recent common ancestor of all Furnariidae did not have adaptations for tail-assisted climbing (Claramunt, et al., 2012). Notwithstanding foraging behavior, there have also been authors who have related the increases in post-orbital and squamosal processes with the behaviors of nest-digging on earthen banks, as observed by Pascotto and Donatelli (2003) in Momotidae. According to Zyskowski and Prum (1999), all Sclerurus species make their nests in holes on earthen banks, which are excavated by the birds themselves. Based on these characters, the authors placed Hyloctistes subulatus, Automolus leucophthalmus, and Thripadectes melanorhynchus close to Sclerurus, because aside from digging holes on earthen banks, these species also use a single plant species to line the egg chamber. Using tail structures, Tubaro et al. (2002) performed a cladistic analysis of Dendrocolaptidae and Furnariidae and coincidentally placed the same species described by Zyskowski and Prum (1999) close to the only Sclerurus species they studied, $S$. scansor. For Irestedt et al. (2006), the ability of Furnariidae to build nests with extremely diverse architecture may be one explanation for the successful colonization of a wide range of habitats. Moreover, coupled with a special modification in cranial kinesis, has allowed the group to occupy the diverse available vegetation strata (Fjeldså, et al., 2005). For Irestedt et al. (2006), environmental factors clearly select morphological modifications in birds, and certain morphological characteristics are repeatedly observed in phylogenetically distant species that occupy forest habitats; this also are shared by species that inhabit open habitats. These aspects are reflected in the irradiation of Dendrocolaptidae-Furnariidae, which includes examples of morphological parallelism among phylogenetically distant species with similar adaptations (Remsen, 2003).

Although still incipient, it is possible to relate changes in the morphology of Furnariidae with climate and geological changes that occurred in the Neotropics, considering that the divergence of its first lineages from the other Suboscines, occurred around 35 million years ago (Claramunt, et al., 2011). The Suboscines lineage evolved with relatively constant rates with a significant increase in species diversification around 15 million years. This coincides with the appearance of the first members of Furnariinae that occupied more 
open and arid areas, while members of Dendrocolaptinae and Slerurinae remained in more closed areas as rainforests (Derryberry, et al., 2011). Members of Furnariidae had an entire continent and a period of time with severe climate change allied to major geological events (Andes appearance with consequent changes at Amazon and Paraná basins). Such events created barriers to geographical dispersion and also a number of new habitats, that Furnariidae were able to occupy (Derryberry, et al., 2011). Moreover, fragmented landscapes that nurture insulation were relatively common, increasing the effect of diversification and cladogenesis within Furnariidae (Claramunt, et al., 2011). This might have provided the greatest morphological diversity within the Suboscines, which evolved in different cladogenesis rates mainly on the basis of Furnariidae Dendrocolaptidae-clade, because Dendrocolaptidae's diversity is much greater than that observed in Scleruridae (Claramunt, 2010). These differences in cladogenesis rate may be explained whether one observes the relationship between the ability of dispersion and adaptation of climbing on tree trunks. Perching birds flight a few meters between trees during foraging behavior, while those that feed on forest soil (as Sclerurus) need not to take long flights to move around in their foraging substrate (Claramunt, et al., 2012). Instead, factors related to the distribution and dispersal abilities of lineages may influence speciation rates more directly through their influence on levels of gene flow and opportunities for geographic isolation (Claramunt, et al., 2011).

Thus, even being a morphologically homogenous genus, Sclerurus differs from other Furnariidae in the following characteristics: a narrowed caudal portion of the nostril with a more rounded shape allowing upper's jaw greater mobility, used when foraging on soft substrates; the development of the post-orbital process may be related to digging behavior; the increased visual field may provide an increase in the ability of Sclerurus for insect and other small arthropods hunting which are its preferred diet.

\section{RESUMEN}

Osteología craneal comparativa en el género Sclerurus (Passeriformes: Furnariidae). La familia Furnariidae está compuesta por 293 especies y ha sido reconocida como un ejemplo de la adaptación continental a la radiación. Habitan biomas de desiertos a bosques húmedos en todos los estratos y muestran heterogeneidad morfológica sin precedentes entre las aves de cualquier nivel taxonómico. Sclerurus es un género uniforme de crípticos, principalmente furnáridos café oscuro con colas negras cortas, que pueden ser encontrados solitarios o cerca del suelo dentro del bosque húmedo. El objetivo del presente estudio fue describir y comparar la osteología craneal de las seis especies de Sclerurus (S. scansor, S. mexicanus, $S$. guatemalensis, $S$. caudacutus, $S$. rufigularis y $S$. albigularis) para identificar los caracteres osteológicos que son (1) únicos de cada especie, (2) compartidos entre las especies, y (3) exclusivos de género cuando se comparan con otros miembros de Furnariidae. Los resultados mostraron que Sclerurus difiere de otro Furnariidae en las siguientes características: un estrechamiento de la porción caudal de la fosa nasal con una forma más redondeada que permite una mayor movilidad de la mandíbula superior, usada durante la recolección de sustratos blandos; el desarrollo del proceso post-orbital puede estar relacionado con el comportamiento de excavación así como la presencia de una corta proyección "parsphenoid rostrum", una reducida prominencia cerebelar, y una cónica porción caudal de las fosas nasales. Entre las especies, la anchura interorbital es mayor en $S$. caudacutus y $S$. rufigularis, que en las especies restantes. El desarrollo del proceso post-orbital puede estar asociado con el comportamiento de excavación de nidos en los bancos de barro; el estrechamiento en la porción caudal de la fosa nasal permite una mayor movilidad del maxilar superior, que es usado por el Sclerurus cuando se alimenta de sustratos blandos en suelos forestales.

Palabras clave: horneros, Scleruridae, anatomía, sistemática.

\section{REFERENCES}

Baumel, J., King, A. S., Lucas, A. M., Breazile, J. E., \& Evans, H. E. (1993). Nomina anatomica avium. London: Academic Press.

Bock, W. J., \& Mcevey, A. (1969). Osteology of Pedionomus torquatus (Aves: Pedionomidae) and its allies. Proceedings of the Royal Society of Victoria, 82, 187-232.

Burton, P. J. K. (1984). Anatomy and evolution of the feeding apparatus in the avian orders Coraciformes and Piciformes. Bulletin of British Museum (Natural History) Zoology, 47, 331-443. 
Chesser, R. T. (2004). Molecular systematics of New World Suboscine birds. Molecular Phylogenetics and Evolution, 32, 11-24.

Chesser, R. T., Barker, F. K., \& Brumfield, R. T. (2007). Fourfold polyphyly of the genus formerly known as Upucerthia, with notes on the systematics and evolution of the avian subfamily Furnariinae. Molecular Phylogenetics and Evolution, 44, 1320-1332.

Claramunt, S. (2010). Discovering exceptional diversifications at continental scales: the case of the endemic families of Neotropical suboscine passerines. Evolution, 64(7), 2004-2019.

Claramunt, S., Derryberry, E. P., Brumfield, R. T., \& Remsen Junior, J. V. (2012). Ecological opportunity and diversification in a continental radiation of birds: climbing adaptations and cladogenesis in the Furnariidae. American Naturalist, 179(5), 649-666.

Claramunt, S., Derryberry, E. P., Remsen Junior, J. V., \& Brumfield, R. T. (2011). High dispersal ability inhibits speciation in a continental radiation of passerine birds. Proceedings of the Royal Society B, 279, 1567-1574.

D’Horta, F. M., Cuervo, A. M., Ribas, C. C., Brumfield, R. T., \& Miyaki, C. Y. (2013). Phylogeny and comparative phylogeography of Sclerurus (Aves: Furnariidae) reveal constant and cryptic diversification in an old radiation of rain forest understorey specialists. Journal of Biogeography, 40, 37-49.

Derryberry, E. P., Claramunt, S., Chesser, R. T., Remsen Junior., J. V., Cracraft, J., Aleixo, A., \& Brumfield, R. T. (2011). Lineage diversification and morphological evolution in a large-scale continental radiation: the Neotropical ovenbirds and woodcreepers (Aves: Furnariidae). Evolution, 65(10), 2973-2986.

Donatelli, R. J. (1997). Osteologia e miologia cranianas de Dendrocolaptidae (Passeriformes, Tyranni). Gêneros Glyphorynchus, Campylorhamphus, Dendrocincla, Xiphorhynchus e Dendrocolaptes. Revista Brasileira de Ornitologia, 5, 19-37.

Donatelli, R. J., \& Marceliano, M. L. (2007). Osteologia e miologia cranianas de Megaxenops parnaguae (Furnariidae: Philydorinae). Boletim do Museu Paraense Emílio Goeldi, Ciências Naturais, 2, 183-215.

Feduccia, A. (1973). Evolutionary trends in the Neotropical ovenbirds and woodhewers. ornithological monographs. American Ornithologist's Union, 13, 1-69.

Fjeldså, J., Irestedt, M., \& Ericson, P. G. P. (2005). Molecular data reveal some major adaptational shifts in the early evolution of the most diverse avian family, the Furnariidae. Journal of Ornithology, 146, 1-13.
Furbringer, M. (1888). Untersuchumgen zur morphologic und systematik der Vögel. Amsterdan: Von Holkema.

Hellmayr, C. E. (1925). Catalogue of birds of the Americas. Field Museum of Natural History Publication Zoological Series, 13, 1-390.

Irestedt, M., Fjeldsa, J., \& Ericson, P. G. P. (2004). Phylogenetic relationships of woodcreepers (Aves: Dendrocolaptinae)-incongruence between molecular and morphological data. Journal of Avian Biology, $35,280-288$.

Irestedt, M., Fjeldså, J., \& Ericson, P. G. P. (2006). Evolution of the ovenbird-woodcreeper assemblage (Aves: Furnariidae)- major shifts in nest architecture and adaptive radiation. Journal of Avian Biology, 37, 260-272.

Irestedt, M., Fjeldså, J., Johansson, U. S., \& Ericson, P. G. P. (2002). Systematic relationships and biogeography of the tracheophone suboscines (Aves: Passeriformes). Molecular Phylogenetics and Evolution, 23, 499-512.

Irestedt, M., Johansson, U. S., Parsons, T. J., \& Ericson, P. G. P. (2001). Phylogeny of major lineages of suboscines (Passeriformes) analysed by nuclear sequence data. Journal of Avian Biology, 32, 15-25.

Leisler, B. (1977). Komorphologische Aspekte von Speziation und adaptiver Radiation bei Vögeln. Vogelwarte, 29, 136-153.

Mestre, L. A., Cohn-Half, M., \& Dias, M. M. (2010). Diet and Prey Availability of Terrestrial Insectivorous Birds Prone to Extinction in Amazonian Forest Fragments. Brazilian Archives of Biology and Technology, 53, 1371-1381.

Moyle, R. G., Chesser, R. T., Brumfieldd, R. T., Telloa, J. G., Marchese, D. J., \& Cracraft, J. (2009). Phylogeny and phylogenetic classification of the antbirds, ovenbirds, woodcreepers, and allies (Aves: Passeriformes: infraorder Furnariides). Cladistics, 25, 1-20.

Olson, S. R., Irestedt, M., Ericson, P. G. P., \& Fjeldså, J. (2005). Independent evolution of two Darwinian marsh-dwelling ovenbirds (Furnariidae: Limnornis, Limnoctites). Ornitologia Neotropical, 16, 347-359.

Pascotto, M. C., \& Donatelli, R. J. (2003). Cranial osteology of Momotidae (Aves, Coraciiformes). Journal of Morphology, 258, 32-48.

Remsen, J. V. (2003). Family Furnariidae (Ovenbirds). In J. Del Hoyo, A. Elliott, \& D. Christie (Eds.), Handbook of the Birds of the World. Broadbills to Tapaculos (pp. 162-357). Cambridge U.K. and Barcelona: BirdLife International and Lynx Edicions. 
Ridgely, R. D., \& Tudor, G. (1994). The birds of South America (Vol. 2). Austin: University of Texas Press.

Sclater, P. L. (1862). Catalogue of a Collection of American Birds. London: N. Trubner \& Co.

Sibley, C. G., \& Ahlquist, J. E. (1990). Classification of birds based on DNA-DNA hybridization. In C. G. Sibley \& J. E. Ahlquist (Eds.), Phylogeny an classification of birds: a study in molecular evolution. (pp. 253-264). New Haven: Yale University Press.

Skutch, A. F. (1969). Life histories of Central American birds: Pacific Coast Avifauna (Vol. 35). Berkeley: Cooper Ornithological Society.

Swainson, W. (1827). On several groups and forms in ornithology, not hitherto defined. Zoological Journal, $3,343-363$.

Tubaro, P. L., Lutmaer, D. A., Palacios, M. G., \& Kopuchian, C. (2002). Adaptative modification of tail structure in relation to body mass and buckling in woodcreepers. The Condor, 104, 281-296.
Van Els, P., \& Whitney, B. M. (2011). Arboreal roosting as a possible explanation for tail stiffnes in the genus Sclerurus. Ornitologia Neotropical, 22, 477-479.

Vaurie, C. (1971). Classification of the ovenbirds (Furnariidae). London: H. F. \& G. Whiterby.

Vaurie, C. (1980). Taxonomy and geographical distribution of the Furnariidae (Aves, Passeriformes). Bulletin of the American Museum of Natural History, 166, 1-357.

Zusi, R. L. (1984). A functional and evolutionary analysis of rhynchokinesis in birds. Smithsonian Contributions to Zoology, 395, 1-40.

Zusi, R. L. (1993). Patterns of diversity in the avian skull. In J. Haken, \& B. K. Hall (Eds.), The skull (Vol. 2). Chicago: Chicago University Press.

Zyskowski, K., \& Prum, R. O. (1999). Phylogenetic analysis of the nest architecture of neotropical ovenbirds (Furnariidae). Auk, 116, 891-911. 